\title{
Physicochemical Analysis of Graphene Oxide-Reinforced Cassava Starch Biocomposites
}

\author{
Nurul Nabilah M. Zaki ${ }^{1}{ }^{(\mathbb{D})}$, Muhamad Yuzaini Azrai M. Yunin ${ }^{1(\mathbb{D})}$, Norfatihah M. Adenam ${ }^{1(\mathbb{D})}$ \\ An'Amt M. Noor ${ }^{1}$ (D), Khairul Nizar Syazwan W. S. Wong ${ }^{2,3}$ (D), Nooraini Yusoff ${ }^{2,3}$ (D), \\ Hasyiya Karimah Adli 2,3,* (D) \\ 1 Faculty of Bioengineering and Technology, Universiti Malaysia Kelantan, 17600, Jeli, Kelantan, Malaysia \\ 2 Institute for Artificial Intelligence \& Big Data, Universiti Malaysia Kelantan, City Campus, Taman Bendahara, 16100, \\ Kota Bharu, Kelantan, Malaysia \\ 3 Data Science Department, Universiti Malaysia Kelantan, City Campus, Taman Bendahara, 16100, Kota Bharu, Kelantan, \\ Malaysia \\ * Correspondence: hasyiya@umk.edu.my (H.K.A.);
}

Scopus Author ID 54884372700

Received: 6.01.2021; Revised: 28.01.2021; Accepted: 1.02.2021; Published: 8.02.2021

\begin{abstract}
Despite the proven application of cassava starch as biocomposites, the starch still has several drawbacks in physical and mechanical properties that need to improve to ensure its commercialization in the future. Thus, in this study, the modification of cassava starch-based (CP) properties was made by adding graphene oxide (GO) filler into cassava starch solution via starch intercalation method. Several physicochemical analyses were performed using Fourier-Transform Infrared (FTIR) Spectrometer and Scanning Electron Microscopy (SEM). The effects of GO content in different concentrations to the mechanical, water uptake, biodegradation, and fungi observation under the microscope were also determined. FTIR spectra of GO-reinforced cassava exhibited all significant peaks from CP and GO present. SEM images show an irregular texture and layered structure of GO. The biocomposites produced from 10\% GO (C10) has superior properties with a tensile strength of $1.60 \mathrm{MPa}$, Young Modulus of $189 \mathrm{MPa}$, and elongation at a break of $2.88 \mathrm{~mm}$. The decrease of residual weight and water uptake percentages at higher concentrations of GO elucidate the biocomposites' enhanced properties. The improved resistance against fungus also resulted from the incorporation of GO into the cassava starch matrix.
\end{abstract}

Keywords: cassava starch; graphene oxide; biocomposites; physicochemical.

(C) 2021 by the authors. This article is an open-access article distributed under the terms and conditions of the Creative Commons Attribution (CC BY) license (https://creativecommons.org/licenses/by/4.0/).

\section{Introduction}

In these recent years, biopolymer, biochemical, and biocomposites have gained interest in a few industrial sectors, such as the food industry and electrical sectors. These biomaterials promote several advantages, such as adding value to by-products, biodegradability, and low energy consumption in their production. In the food industry, the proper or desirable packaging must have proper mechanical strength, low water absorption, thermal stability, and biodegradability to ensure the products' safety and shelf life [1,2]. The most common packaging is made from petroleum-based materials such as polypropylene (PP), polyethylene (PE), and polystyrene (PS) [3]. However, this type of material has caused a few environmental issues as it is non-degradable. Hence, to solve this problem, the plastic from petroleum-based materials 
can be substituted into biopolymer (e.g., starch, agar, and gelatin) to develop their biodegradability properties.

Biocomposites are biodegradable materials that can degrade easily by microorganisms, such as bacteria and fungi [4]. Recent biocomposites mostly use biodegradable materials from microalgae [5], fruit waste [6], and starch [7,8]. The biocomposites derived from cassava starch or known as Manihot Esculenta sp. have shown the most promising material. Cassava contains around $90 \%$ of starch composed of two kinds of polysaccharides, called amylose and amylopectin (Figure 1) [9], and small contents of lipids, proteins, and fibers [10].

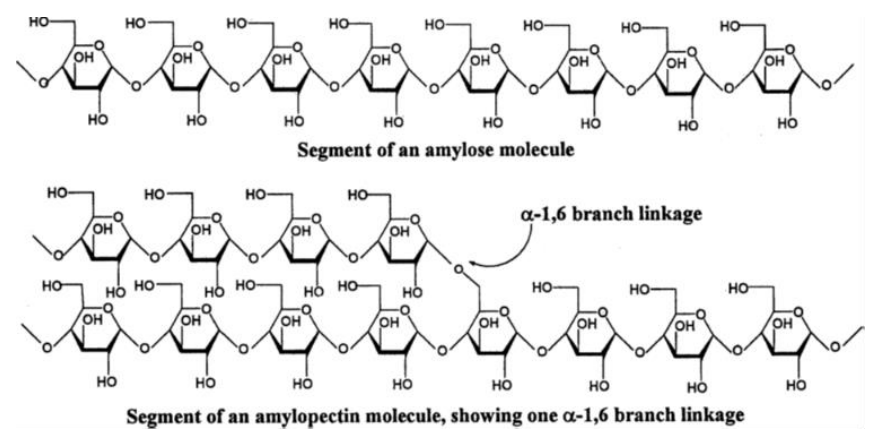

Figure 1. The chemical structures of amylose and amylopectin molecules of starch.

Despite the proven application of cassava starch as biocomposites, the starch still has several drawbacks in physical and mechanical properties that need improvement to ensure its commercialization. Thus, in this study, cassava starch's biocomposites properties were modified by mixing graphene oxide (GO) in different concentrations. Considering the characteristics of graphene oxide with high compatibility with various polymers and barrier properties [11,12], this approach was found to enhance the starch structure, leading to the upgrade of the biocomposites properties of pure cassava powder $(\mathrm{CP})$. Based on the literature study, GO as an excellent nanofiller on improving mechanical properties of the resin matrix, for instance, the dispersion of GO in the bismaleimide (BMI) resin which the author reported the flexural strength and flexural modulus of GO/BMI nanocomposites are enhanced by $39.6 \%$ and $45.5 \%$ than BMI resin without GO [13].

\section{Materials and Methods}

\subsection{Materials.}

The commercial cassava powder was purchased from the local market. All chemicals and reagents were used without further purification. Glycerol from R\&M Chemicals was used as received. The oxidation of graphite was started by mixing sulphuric acid, phosphoric acid, and potassium permanganate (Merck, USA). Then, hydrogen peroxide (Merck, USA) was added to stop the oxidation process. Later, the graphite oxide was washed with hydrochloric acid (Merck, USA) aqueous solution and deionized water until $\mathrm{pH}$ of 4-5 is achieved and the GO solution is formed.

\subsection{Synthesis of cassava starch/graphene oxide biocomposites.}

The synthesis of biocomposites was carried out using a solution intercalation method. $5 \mathrm{~g}$ of commercial cassava starch was dissolved into $40 \mathrm{~mL}$ of distilled water and mixed with $1.5 \mathrm{~g}$ of glycerol before stir on the hot plate until a sticky paste was formed. As-formed paste solution was let to dry on the petri dish at room temperature to ensure solidification. A similar 
method was used to prepare biocomposites from cassava starch/graphene oxide by adding graphene oxide solutions in different concentrations $(1 \%, 3 \%, 6 \%$, and $10 \%)$ into the prepared cassava starch solution. A series of prepared solutions were then denoted as CP, C1, C3, C6, and $\mathrm{C} 10$ for pure cassava, cassava starch/graphene oxide (1\%), cassava starch/graphene oxide (3\%), cassava starch/graphene oxide $(6 \%)$ and cassava starch/graphene oxide (10\%), respectively.

\subsection{Characterization.}

The physicochemical analysis was performed using Fourier Transform Infrared (FTIR) Spectrometer (Thermos Scientific Nicolet iZ10) and Scanning Electron Microscopy (SEM) (Jeol JSMIT100) with several mechanical tests such as tensile test, moisture absorption, biodegradability, and fungi observation under an optical microscope. FTIR analysis was run in the range of $4000 \mathrm{~cm}^{-1}$ until $400 \mathrm{~cm}^{-1}$ to characterize the functional groups that present in the sample. SEM analysis was carried out at $150 \times$ and $300 \times$ magnification to observe the changes of surface morphology. The samples' mechanical properties were measured by a Universal Testing Machine using a tensile tester with a load capacity of $2000 \mathrm{~N}$. The prepared biocomposites were cut into $5 \times 3 \mathrm{~cm}^{2}$ and clamped at both ends before pulled with a constant speed of $3000 \mathrm{~mm} \mathrm{~min}^{-1}$. The biodegradable behavior of prepared biocomposites was determined using the soil burial decomposition test [14]. All prepared biocomposites were cut into $5 \times 3 \mathrm{~cm}^{2}$ before buried in the ground at $15 \mathrm{~cm}$ depth; the burial duration varied from week 1 until week 3 . Before burial, the initial weight was determined, and the final weight (weight after decomposition) of the biocomposites was measured. The decomposition of each sample was calculated based on Equation 1 [15].

$$
\text { Residual Weight }(\%)=(\text { Final weight }- \text { Initial weight }) / \text { Initial weight } \times 100 \%
$$

For water absorption, the measurement was carried out at relative humidity of $80 \%$ at room temperature to identify prepared biocomposites' ability to absorb the water [13]. The prepared biocomposites were cut into $5 \times 3 \mathrm{~cm}^{2}$ and weighed for initial weight before soaking into distilled water for $45 \mathrm{~min}$ at ambient temperature. After that, the samples were removed, wiped off, and immediately weighed again as final weigh. The water absorption capacity of prepared biocomposites can be calculated based on Equation 2.

Water absorption $(\%)=($ Initial weight - Final weight $) /$ Initial weight $\times 100 \%$

Meanwhile, the fungus observation under RaxVision Y100 optical microscope was performed to investigate prepared biocomposites' resistivity against fungus. The test was conducted by spraying water onto biocomposites and kept them for 4 weeks at room temperature. The observation by naked eyes and under the optical microscope was done during the period.

\section{Results and Discussion}

\subsection{Fourier-transform infrared analysis (FT-IR) analysis.}

The prepared cassava starch-based biocomposites should consist of the starch as the matrix and the constituent fillers, prepared by mixing the starch with glycerol plasticizer and graphene oxide filler. At first, the glycerol molecule enlarges the formed cavity. The matrix of 
starch becomes more elastic, which affects the elongation value [16]. Graphene oxide (GO) can be diffused in aqueous media, which introduces some oxygen-containing surface functional group [17] to promote the interactions between host matrix and GO through the formation of covalent and non-covalent bonds [18,19]. The addition of graphene oxide fills the cavities to form more dense and influence cassava starch-based biocomposites' mechanical properties. Hence, it is expected that the hydroxyl groups from the cassava starch, glycerol, and graphene oxide would interact with each other to form the oxygen bridge and water by-products [20,21], as illustrated in Figure 2.

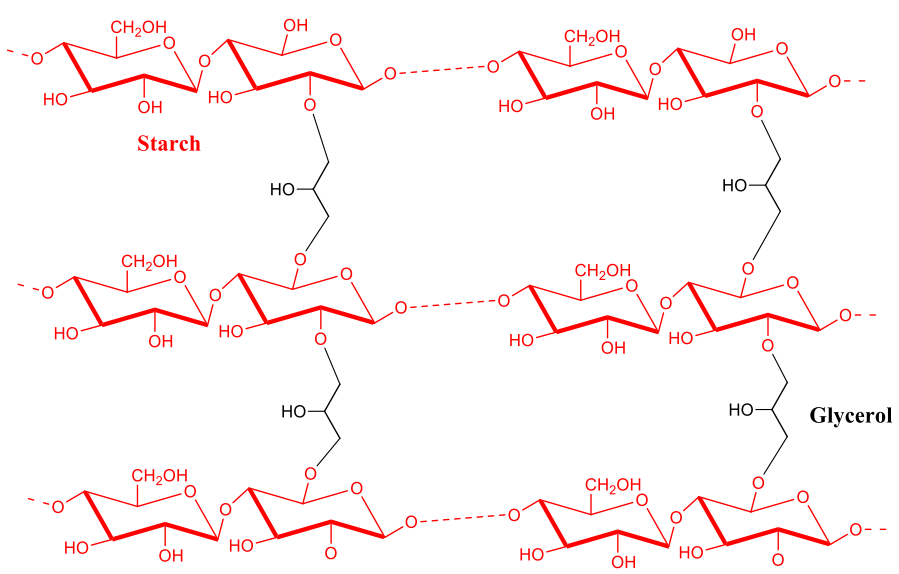

(a)

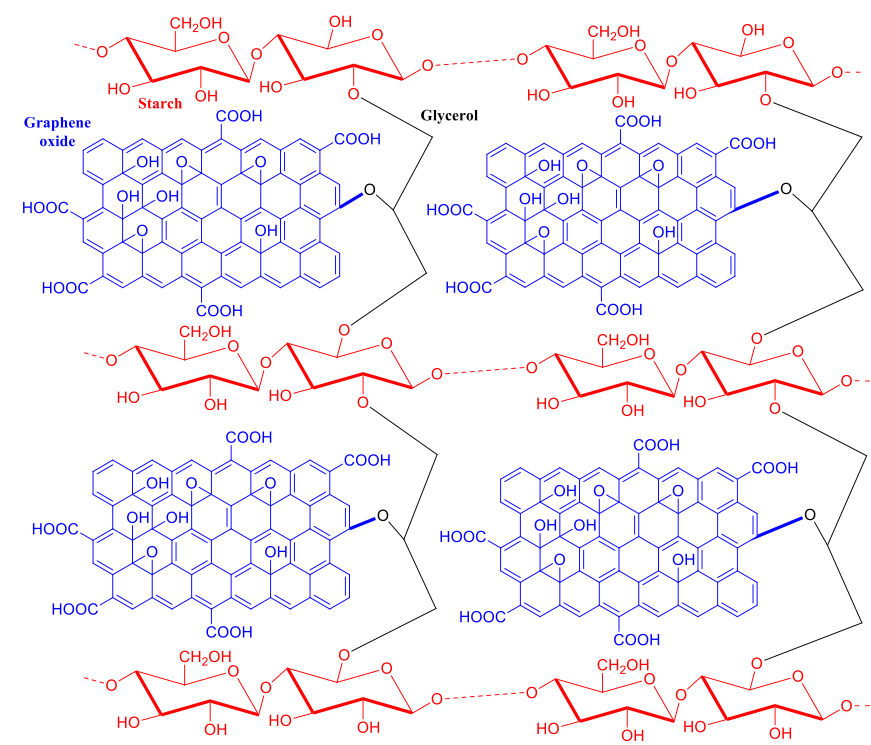

(b)

Figure 2. The chemical interaction between cassava starch and glycerol (a), and graphene oxide (b).

In this work, FT-IR analysis is carried out to identify the functional groups present in cassava starch-based (CP) with and without GO. Based on the FTIR spectrum pattern of CP, it can be seen that it has low absorption intensity, especially for $\mathrm{O}-\mathrm{H}\left(3277 \mathrm{~cm}^{-1}\right)$ and $\mathrm{C}-\mathrm{H}(3277$ $\mathrm{cm}^{-1}, 1600 \mathrm{~cm}^{-1}$ ), with peaks at $1076.45 \mathrm{~cm}^{-1}$ and $1149.23 \mathrm{~cm}^{-1}$ attributed to C-O stretching. Based on the GO spectrum, the observed peaks represent hydrogen bond $(-\mathrm{OH})$ stretching at $3316.75 \mathrm{~cm}^{-1}$ and $1636.12 \mathrm{~cm}^{-1}$ that correspond to $\mathrm{C}=\mathrm{O}$ bonds present at the edges of the graphene oxide layer [22]. When $\mathrm{CP}$ is added with $\mathrm{GO}$ (which represents $\mathrm{C} 1, \mathrm{C} 3$ and $\mathrm{C6}$ ), all significant peaks from $\mathrm{CP}$ and $\mathrm{GO}$ were present, indicating the mixture of $\mathrm{CP}$ and GO was successfully prepared. From the C1, C3, and C6 spectrum, $(-\mathrm{OH})$ stretching at around 3300 
$\mathrm{cm}^{-1}$ and $1650 \mathrm{~cm}^{-1}$ is found strengthened, indicating an interaction between the $\mathrm{CP}$ and GO that creates intermolecular and intramolecular hydrogen bonds. Furthermore, stronger peak absorption in the wavelength range from 2800 until $3000 \mathrm{~cm}^{-1}$, which represents an increase of the $\mathrm{C}-\mathrm{H}$ bond by the addition of GO. The FTIR spectra of biocomposites, graphene oxide, and their composites are presented (Figure 3).

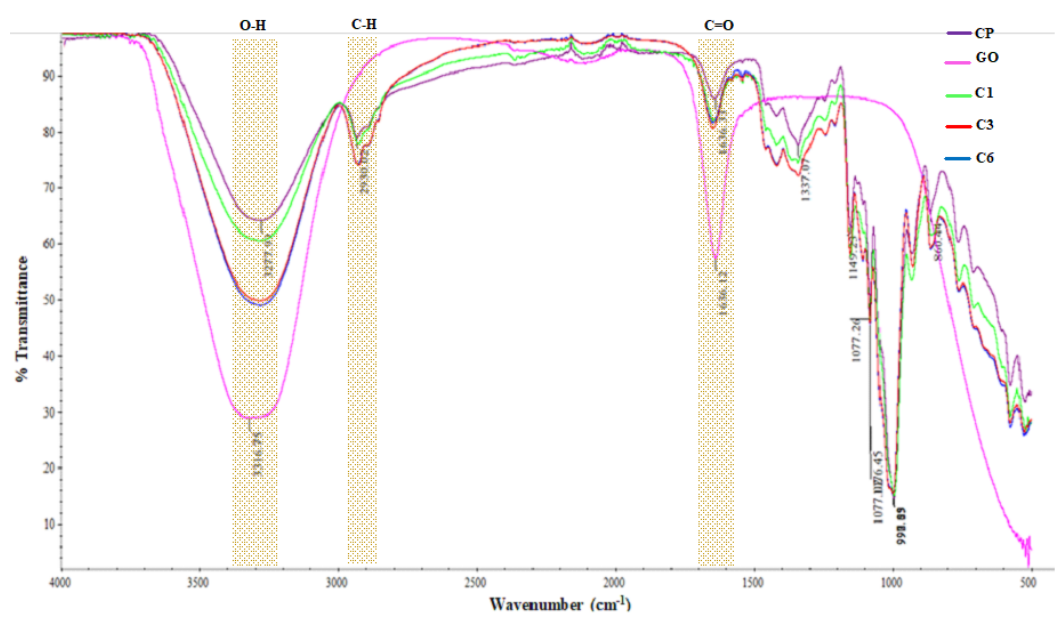

Figure 3. The FTIR spectra of biocomposites, graphene oxide, and their composites.

\subsection{Scanning electron microscopy (SEM) analysis.}

SEM surface morphology of cassava (CP) and that prepared cassava-starch biocomposites ( $\mathrm{C} 1, \mathrm{C} 6$, and $\mathrm{C} 10)$ were viewed to elucidate their morphology, as shown in Figure 4. CP (Figure 4A) exhibits fewer walls built, indicating a fragile starch structure [23,24]. However, with the addition of GO at different concentrations (Figure 4B-D), the surface morphology exhibits irregular texture and a more layered structure that represents the structure of morphology of GO [25,26-29]. Besides, GO appeared to form covered on the surface of cassava starch $[24,30]$.

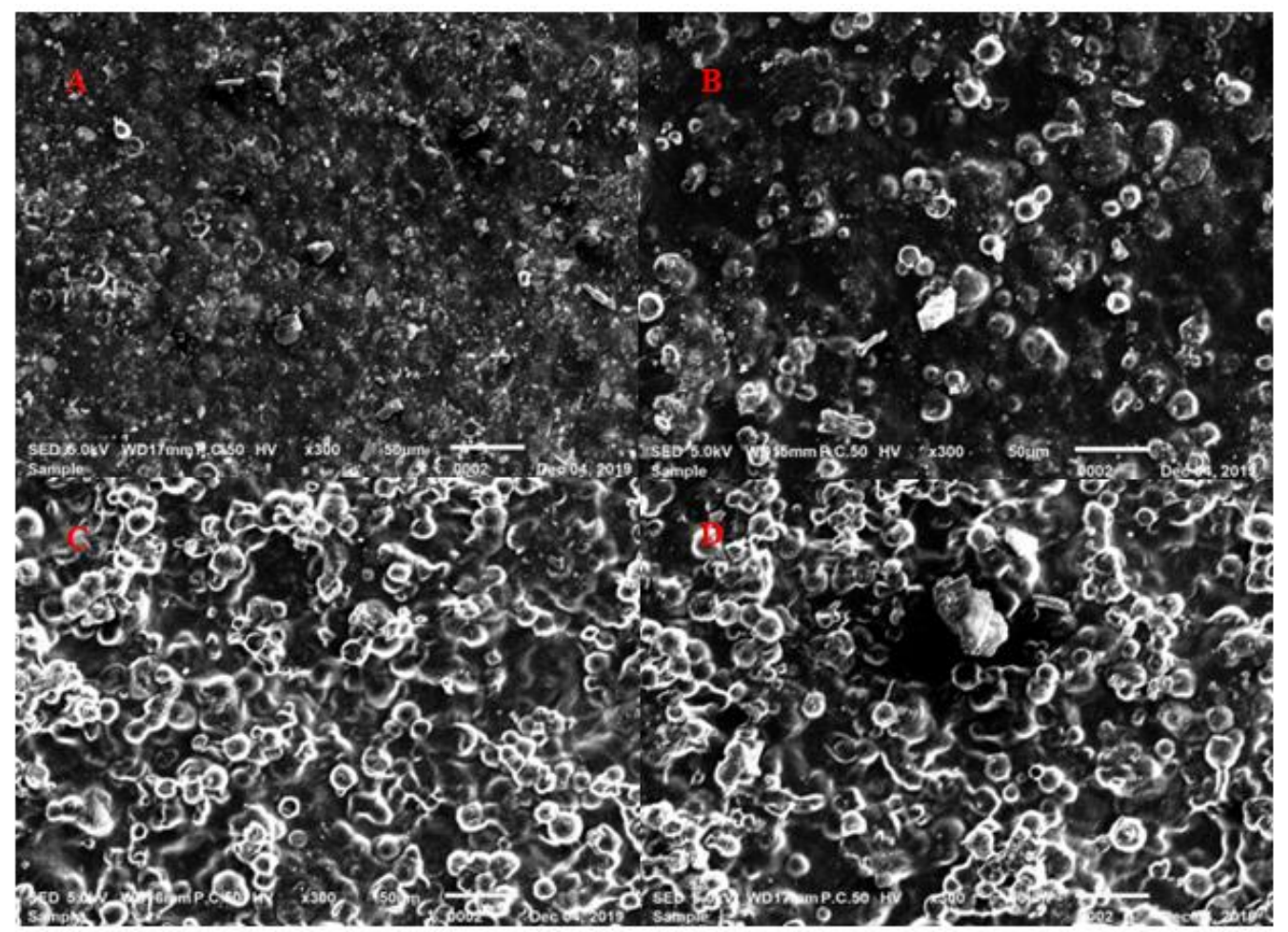

Figure 4. Surface morphology of (A-D); CP, C1, C6, and C10 respectively at 300× magnification. 
The obtained SEM images show cassava-starch-based biocomposites formed from the mixture between GO, cassava starch-based, and glycerol.

\subsection{Tensile strength analysis.}

Figure 5 shows the tensile strength (MPa) trend of $\mathrm{CP}, \mathrm{C} 1, \mathrm{C} 3, \mathrm{C} 6$, and $\mathrm{C} 10$. It can be seen that with GO addition, the tensile strength increased from $0.6 \mathrm{MPa}$ to $0.9 \mathrm{MPa}$, and the value increased gradually with a higher concentration of GO. The highest value by $\mathrm{C} 10$ that consists of $10 \% \mathrm{GO}$, recorded with a tensile strength of $1.6 \mathrm{MPa}$, increased up to $56 \%$ from C1 (1\% GO). The improvement of tensile strength can be explained due to the good interfacial interaction of GO with cassava-based starch within the GO/CP matrix [31]. The increased pattern was also reported previously for other starch-based and polymers, whereby the tensile strength increased remarkably with the addition of GO nanocomposites [32-34].

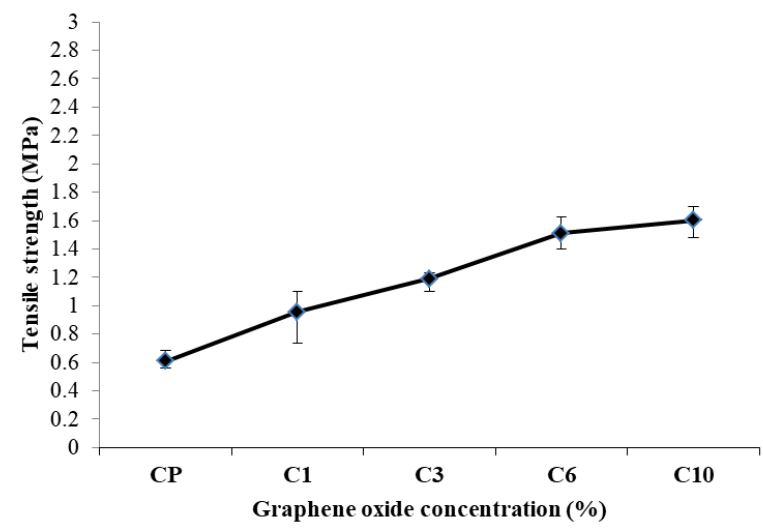

Figure 5. The tensile strength of biocomposites.

\subsection{Young modulus analysis.}

Young modulus is a useful parameter to indicate the stiffness characteristics of any film [35]. As illustrated (Figure 6), the value shows increased with an increasing GO concentration, with $\mathrm{C} 10$ having the highest value of $189 \mathrm{MPa}$. The value gains about three times from $59 \mathrm{MPa}$ of cassava-starch based without GO to $189 \mathrm{MPa}$ of cassava-starch based biocomposites that contain $10 \%$ GO. Overall results highlighted that with the modification of CP with GO as filler, the mechanical properties were significantly changed $[36,27,28]$.

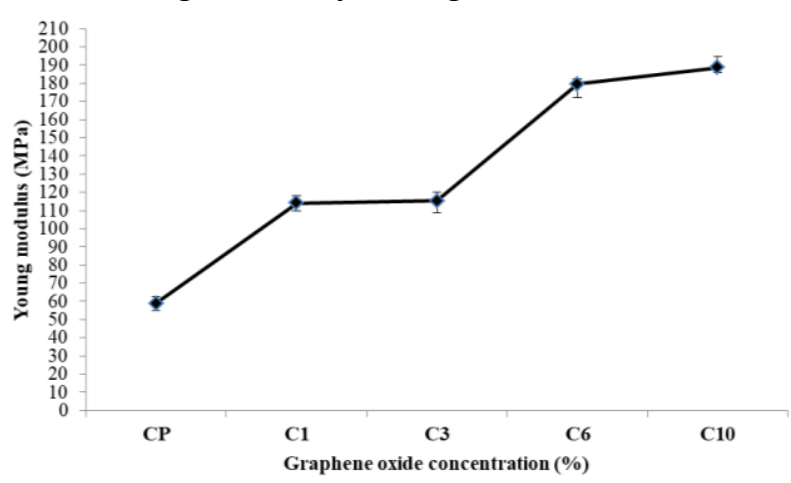

Figure 6. The Young modulus of biocomposites.

\subsection{Elongation at break analysis.}

Elongation at break is the maximum change of the biocomposites can stretch before it breaks, and this is a significant parameter to analyze the mechanical properties of biocomposite 
materials [37]. Figure 7 shows the result of graphene oxide (GO) concentration against the elongation at break of $\mathrm{CP}, \mathrm{C} 1, \mathrm{C} 3, \mathrm{C} 6$, and $\mathrm{C} 10$. It can be observed that with increasing concentration of GO, the value was gradually decreased from $4.2 \mathrm{~mm}$ of $\mathrm{CP}$ to $2.8 \mathrm{~mm}$ of C10. It can be explained because of $\mathrm{GO}$, as the filler internally reduces hydrogen bonds that cause the polymer chain to break up [30,34].

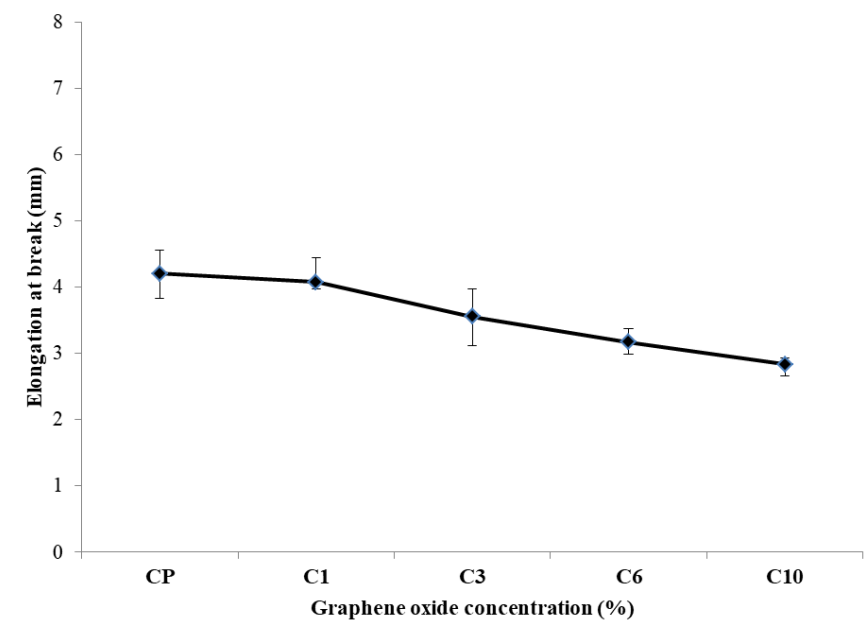

Figure 7. The elongation at break of biocomposites.

\subsection{Biodegradation analysis.}

Biodegradation analysis was conducted to determine any materials' ability to degrade and leave no residue that brings harmful effects to the environment [38]. The obtained result (Figure 8) shows that $\mathrm{CP}$ has the highest residual weight of about $50 \%$ even after week 3 . The cassava-starch based is known for having an amylose and amylopectin structure that easily degrades in the soil environment [39]. Besides, both starch and glycerol are natural biodegradable polymers that able to decompose in the environment [40]. However, by mixing cassava starch-based with $\mathrm{GO}$, for the case of $\mathrm{C} 1, \mathrm{C} 3, \mathrm{C} 6$, and $\mathrm{C} 10$, the percentage of residual weight recorded much lower compared to $\mathrm{CP}$, indicating that the materials degraded faster. This is related to the hydrophilic properties of GO that improve the hydrophilic properties of the cassava-starch-based composite, making the material more easily degraded [41]. The hydrophilic properties of these materials also were in accordance with FTIR spectra, stated previously. The images of before and after buried in the soil prepared biocomposites demonstrate that less residual of C10 was found than other samples (Table 1).

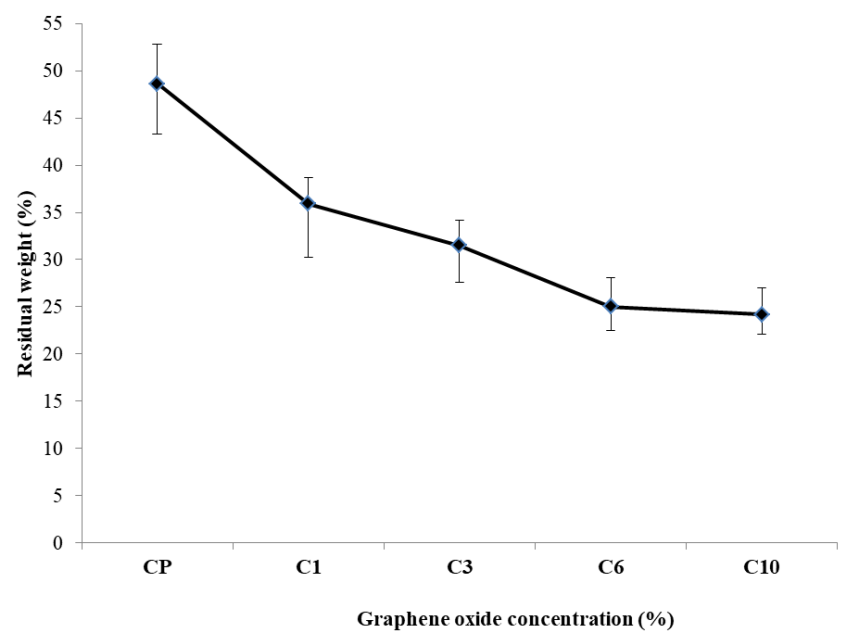

Figure 8. The residual weight of biocomposites. 
Table 1. The observation-based on biodegradation analysis.

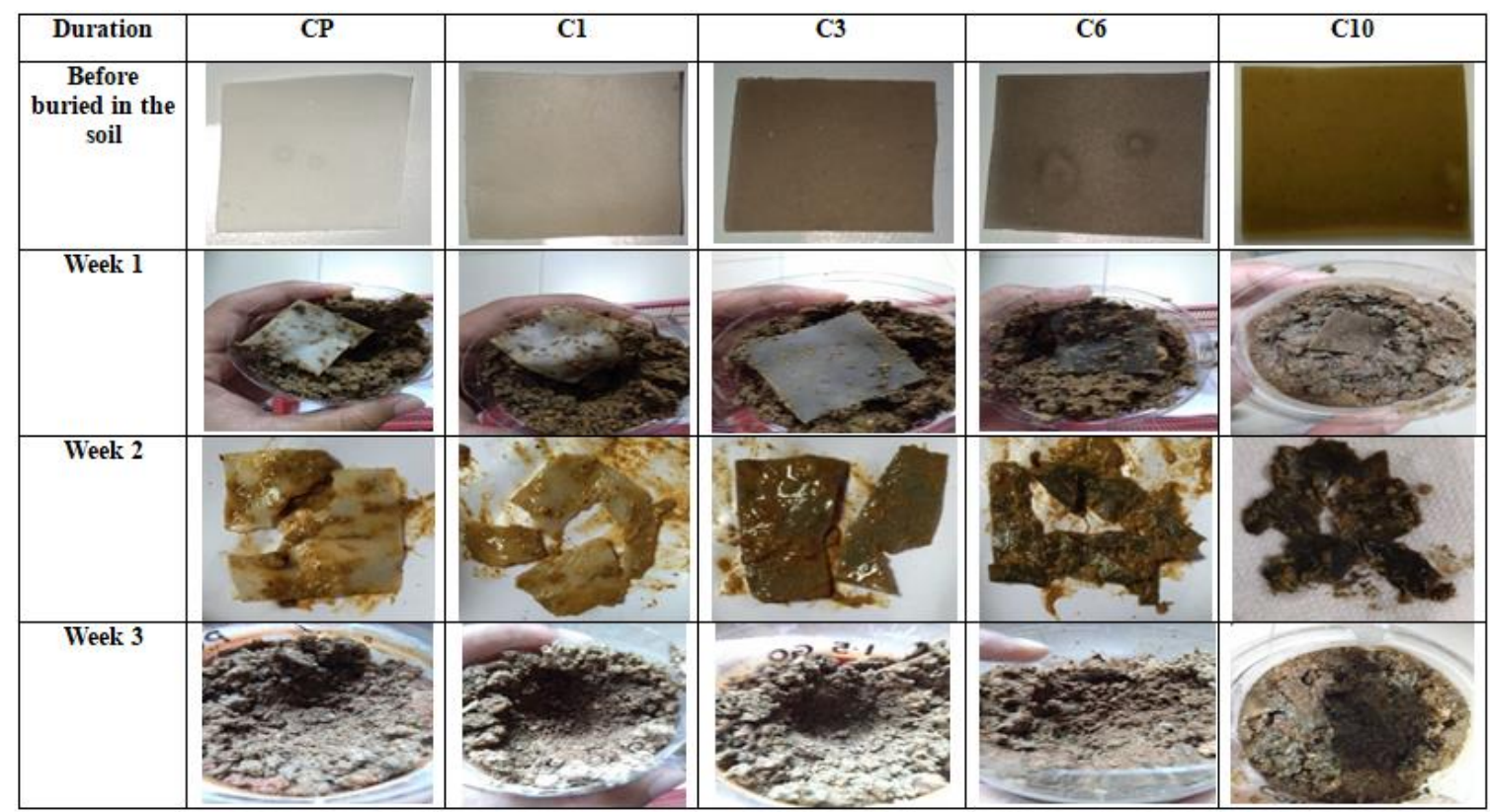

\subsection{Water Uptake Analysis.}

The analysis was conducted to test the ability of materials to absorb water. Figure 9 shows the water uptake of $\mathrm{CP}, \mathrm{C} 1, \mathrm{C} 3, \mathrm{C} 6$, and $\mathrm{C} 10$ in percentage value. It can be seen that water uptake decrease with the increase in GO concentration. The water resistance properties of any materials depend on the nature of that material [42]. In this case, cassava-starch-based and the glycerol have hydrophilic properties as well as GO. Therefore, the addition of GO in the cassava starch-based matrix certainly would enhance hydrophilicity properties. The finding shows $\mathrm{C} 10$ has the lowest percentage of water uptakes, recorded only $18.4 \%$ compared to $\mathrm{CP}$, $\mathrm{C} 1, \mathrm{C} 3$, and C6 with percentage values of $36.5 \%, 25.6 \%, 24.8 \%$, and $18.9 \%$, respectively. It could be attributed to the completeness of the reaction between the cassava starch-based glycerol and GO that form water as a by-product [43]. Eventually, the reaction reaches a watersaturated condition and decreases cassava-starch biocomposites' ability to receive external water [44].

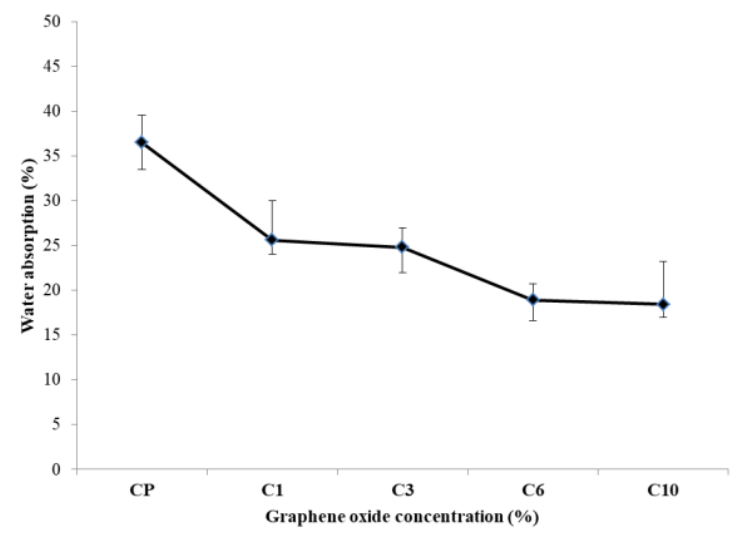

Figure 9. Percentage of water uptake of biocomposites.

\subsection{Observation Under Optical Microscope Analysis.}

The analysis was performed to investigate the resistivity of cassava starch-based biocomposites against fungus. In the first week, $\mathrm{CP}$ and $\mathrm{C} 1$ show the existence of fungus found 
on the biocomposites surface, indicating their low resistivity and stability against fungus (Table 2). However, for $\mathrm{C} 3$, fungus formation was found on the surface after week 3; C6 and C10 were found stable against fungus until week 4. By increasing GO concentration, it can withstand a fungus presence [45-47].

Table 2. Observation under the optical microscope.

\begin{tabular}{|c|c|c|c|c|c|}
\hline Duration & $\mathrm{CP}$ & $\mathrm{Cl}$ & $\mathrm{C} 3$ & C6 & $\mathrm{C} 10$ \\
\hline $\begin{array}{c}\text { Before } \\
\text { sprayed with } \\
\text { water }\end{array}$ & & & & & \\
\hline Week 1 & & & & & \\
\hline Week 2 & & & & & \\
\hline Week 3 & & & & & \\
\hline $\begin{array}{l}\text { Week } 4 \\
\text { (under } \\
\text { optical } \\
\text { microscope) }\end{array}$ & & & & & \\
\hline
\end{tabular}

\section{Conclusions}

In summary, the biocomposites properties of graphene oxide-reinforced cassava starch were evaluated based on FTIR spectra, SEM surface morphology, mechanical, biodegradation, and water uptake analysis, as well as fungi observation. From FTIR and SEM, the findings suggested the successful mixture of CP and GO via the intercalation method. While, through mechanical, biodegradation, and water uptake analysis, the results elucidate the superior properties of $\mathrm{C} 10$ biocomposites among the series. By increasing the GO concentration into the cassava starch matrix, the biocomposites resulted can withstand the fungus.

\section{Funding}

This research received no external funding.

\section{Acknowledgments}

The authors would like to thank the Faculty of Bioengineering and Technology, UMK, for providing an instrumentation facility.

\section{Conflicts of Interest}

The authors declare no conflict of interest. 


\section{References}

1. Haghighi, H.; Licciardello, F.; Fava, P.; Siesler, H.W.; Pulvirenti, A. Recent advances on chitosan-based films for sustainable food packaging applications. Food Packaging and Shelf Life 2020, 26, 100551, https://doi.org/10.1016/j.fpsl.2020.100551.

2. Lee, L.-T.; Ke, Y.-L. Superior Crystallization Kinetics Caused by the Remarkable Nucleation Effect of Graphene Oxide in Novel Ternary Biodegradable Polymer Composites. ACS Omega 2020, 5 (47), 3064330656. https://doi.org/10.1021/acsomega.0c04658.

3. Cottaz, A.; Bouarab, L.; De Clercq, J.; Oulahal, N.; Degraeve, P.; Joly, C. Potential of Incorporation of Antimicrobial Plant Phenolics Into Polyolefin-Based Food Contact Materials to Produce Active Packaging by Melt-Blending: Proof of Concept With Isobutyl-4-Hydroxybenzoate. Frontiers in Chemistry 2019, 7, 148, https://doi.org/10.3389/fchem.2019.00148.

4. Muthusamy, M.S.; Pramasivam, S. Bioplastics-An Eco-friendly Alternative to Petrochemical Plastics. Current World Environment 2019, 14, 49, http://dx.doi.org/10.12944/CWE.14.1.07.

5. Mathiot, C.; Ponge, P.; Gallard, B.; Sassi, J.-F.; Delrue, F.; Le Moigne, N. Microalgae starch-based bioplastics: Screening of ten strains and plasticization of unfractionated microalgae by extrusion. Carbohydr. Polym. 2019, 208, 142-151, https://doi.org/10.1016/j.carbpol.2018.12.057.

6. De Souza Mesquita, L. M.; Martins, M.; Élia, M.; Cláudia, N; Paula, S. G. N. Q.; Ana, C. R. V. D.; João, A. P. C; L, P. P.; V, V. D. R.; Sónia, P.M. V. I onic Liquid-Mediated Recovery of Carotenoids from the Bactris gasipaes Fruit Waste and Their Application in Food-Packaging Chitosan Films. ACS Sustain. Chem. Eng. 2020, 8 (10), 4085-4095. https://doi.org/10.1021/acssuschemeng.9b06424.

7. Ismail, W.M.I.W.; Chien, L.J.; Adli, H.K.; Salleh, H.; Masri, M.N. Conductivity Study of Cassava Starch Coated Anode for Zinc-Air Fuel Cell System. Materials Science Forum 2020, 1010, 301-307, https://doi.org/10.4028/www.scientific.net/MSF.1010.301.

8. Soni, R.; Asoh, T.-A.; Uyama, H. Cellulose nanofiber reinforced starch membrane with high mechanical strength and durability in water. Carbohydr. Polym. 2020, 238, 116203, https://doi.org/10.1016/j.carbpol.2020.116203.

9. Kadokawa, J.-i. Architecture of amylose supramolecules in form of inclusion complexes by phosphorylasecatalyzed enzymatic polymerization. Biomolecules 2013, 3, 369-385, https://doi.org/10.3390/biom3030369.

10. Diabor, E.; Funkenbusch, P.; Kaufmann, E.E. Characterization of Cassava Fiber of Different Genotypes as a Potential Reinforcement Biomaterial for Possible Tissue Engineering Composite Scaffold Application. Fibers Polym 2019, 20, 217-228. https://doi.org/10.1007/s12221-019-8702-9.

11. Tan, B.; Thomas, N.L. A review of the water barrier properties of polymer/clay and polymer/graphene nanocomposites. J. Membr. Sci. 2016, 514, 595-612, https://doi.org/10.1016/j.memsci.2016.05.026.

12. Pierleoni, D.; Xia, Z.Y.; Christian, M.; Ligi, S.; Minelli, M.; Morandi, V.; Doghieri, F.; Palermo, V. Graphene-based coatings on polymer films for gas barrier applications. Carbon 2016, 96, 503-512, https://doi.org/10.1016/j.carbon.2015.09.090.

13. Zhao, X.; Zhou, M.; Peng, Q.; Ding, R.; Li, P.; Chen, Q.; Xu, L.; He, X. Mechanical Properties Improvement in Highly and Aligned Dispersed Graphene Oxide/Bismaleimide Nanocomposites based on Graphene Oxide Sponge. Adv. Eng. Mater. 2020, 22, 2000231 (1-7). https://doi.org/10.1002/adem.202000231.

14. Samira, S.; Hocine, D.; Amar, B. Study of the properties and biodegradability of the native and plasticized corn flour-filled low density polyethylene composites for food packaging applications. Mater. Today 2020, Article in Press. https://doi.org/10.1016/j.matpr.2020.05.317.

15. Marichelvam, M.K.; Jawaid, M.; Asim, M. Corn and rice starch-based bio-plastics as alternative packaging materials. Fibers 2019, 7, 32, https://doi.org/10.3390/fib7040032.

16. Mościcki, L.; Mitrus, M.; Wójtowicz, A.; Oniszczuk, T.; Rejak, A.; Janssen, L. Application of extrusioncooking for processing of thermoplastic starch (TPS). Food Res. Int. 2012, 47, 291-299, https://doi.org/10.1016/j.foodres.2011.07.017.

17. Yu, W.; Sisi, L.; Haiyan, Y.; Jie, L. Progress in the functional modification of graphene/graphene oxide: a review. RSC Advances 2020, 10, 15328-15345, https://doi.org/10.1039/D0RA01068E.

18. Liming, X; Yingying, Z; Weiqiang, Z; Fengxing, J; Hui, Z; Qinglin, J; Yanhua, J; Rui, W; Aiqin, L; Jingkun, $\mathrm{X}$; Xuemin, Duan. Fused Heterocyclic Molecule-Functionalized N-Doped Reduced Graphene Oxide by NonCovalent Bonds for High-Performance Supercapacitors. ACS Appl. Mater. Interfaces 2020, 12 (40), 4520245213. https://doi.org/10.1021/acsami.0c13377. 
19. Jayaramulu, K.; Horn, M.; Schneemann, A.; Saini, H.; Bakandritsos, A.; Ranc, V.; Petr, M.; Stavila, V.; Narayana, C.; Scheibe, B.; Kment, Š.; Otyepka, M.; Motta, N.; Dubal, D.; Zbořil, R.; Fischer, R.A. Covalent Graphene-MOF Hybrids for High-Performance Asymmetric Supercapacitors. Adv. Mater. 2020, n/a, 2004560, https://doi.org/10.1002/adma.202004560.

20. Lam, E.; Luong, J.H.T. Carbon Materials as Catalyst Supports and Catalysts in the Transformation of Biomass to Fuels and Chemicals. ACS Catalysis 2014, 4, 3393-3410, https://doi.org/10.1021/cs5008393.

21. Huamán-Castilla, N.L.; Mariotti-Celis, M.S.; Martínez-Cifuentes, M.; Pérez-Correa, J.R. Glycerol as alternative co-Solvent for water extraction of polyphenols from Carménère pomace: Hot pressurized liquid extraction and computational chemistry calculations. Biomolecules 2020, 10, 474, https://doi.org/10.3390/biom10030474.

22. Kumar, N.; Srivastava, V.C. Simple Synthesis of Large Graphene Oxide Sheets via Electrochemical Method Coupled with Oxidation Process. ACS Omega 2018, 3, 10233-10242, https://doi.org/10.1021/acsomega.8b01283.

23. Lu, H.; Guo, L.; Zhang, L;. Caifeng, X.; Wen, L.; Bi, G.; Kai, L. Study on quality characteristics of cassava flour and cassava flour short biscuits. Food Sci Nutr. 2020, 8, 521- 533. https://doi.org/10.1002/fsn3.1334

24. Duyen, T.T.M; Hung, P.V. Morphology, crystalline structure and digestibility of debranched starch nanoparticles varying in average degree of polymerization and fabrication methods. Carbohydr. 2020, 117424, Article in Press. https://doi.org/10.1016/j.carbpol.2020.117424.

25. Sieradzka, M.; Fabia, J.; Biniaś, D.; Fryczkowski, R.; Janicki, J. The Role of Reduced Graphene Oxide in the Suspension Polymerization of Styrene and Its Effect on the Morphology and Thermal Properties of the Polystyrene/rGO Nanocomposites. Polym. 2020, 12, 1468, 1-13. https://doi.org/10.3390/polym12071468.

26. Manoratne, C.H.; Rosa, S.R.D.; Kottegoda, I.R.M. XRD-HTA, UV visible, FTIR and SEM interpretation of reduced graphene oxide synthesized from high purity vein graphite. Material Science Research India 2017, 14, 19-30, https://doi.org/10.13005/msri/140104.

27. Amri, A.; Ekawati, L.; Herman, S.; Yenti, S.R.; Zultiniar; Aziz, Y.; Utami, S.P.; Bahruddin. Properties enhancement of cassava starch based bioplastics with addition of graphene oxide. IOP Conference Series: Materials Science and Engineering 2018, 345, 012025, https://doi.org/10.1088/1757-899X/345/1/012025.

28. Afshar, S.; Baniasadi, H. Investigation the effect of graphene oxide and gelatin/starch weight ratio on the properties of starch/gelatin/GO nanocomposite films: The RSM study. Int. J. Biol. Macromol. 2018, 109, 1019-1028, https://doi.org/10.1016/j.ijbiomac.2017.11.083.

29. Amri, A.; Hanifa, R.; Evelyn; Awaltanova, E. The effects of graphene oxide functionalization on the properties of sago starch-based bioplastics. IOP Conference Series: Materials Science and Engineering 2018, 420, 012061, https://doi.org/10.1088/1757-899X/420/1/012061.

30. Ávila-Orta, C.A.; Soriano Corral, F.; Fonseca-Florido, H.A.; Estrada Aguilar, F.I.; Solís Rosales, S.G.; Mata Padilla, J.M.; González Morones, P.; Fernández Tavizón, S.; Hernández-Hernández, E. Starch-graphene oxide bionanocomposites prepared through melt mixing. J. Appl. Polym. Sci. 2018, 135, 46037, https://doi.org/10.1002/app.46037.

31. Kim, D.-W.; Shchipunov, Y.; Kim, G.-H.; Shin, I.; Ha, C.-S. Effect of graphene oxide content on the tensile properties and swelling ratio of chitosan/xanthan gum/graphene oxide hydrogel films. Mol Cryst Liq Cryst., 2020, 706:1, 72-78. https://doi.org/10.1080/15421406.2020.1743440.

32. Cheng, Y.; Jing, X.; Yue, X.; Sijia, H.; Zhidong, R. Covalent polymer functionalized graphene oxide/poly(ether ether ketone) composites for fused deposition modeling: improved mechanical and tribological performance. RSC Adv., 2020, 10, 25685-25695. https://doi.org/10.1039/D0RA04418K.

33. Ramezani, H.; Behzad, T.; Bagheri, R. Synergistic effect of graphene oxide nanoplatelets and cellulose nanofibers on mechanical, thermal, and barrier properties of thermoplastic starch. Polym Adv Technol. 2020, 31, 553- 565. https://doi.org/10.1002/pat.4796.

34. Chintalapudi, K.; Rao Pannem, R.M. Strength properties of graphene oxide cement composites, Mater. Today. 2020, In Press. https://doi.org/10.1016/j.matpr.2020.08.369.

35. Santana, R.F.; Bonomo, R.C.F.; Gandolfi, O.R.R.; Rodrigues, L.B.; Santos, L.S.; dos Santos Pires, A.C.; de Oliveira, C.P.; da Costa Ilhéu Fontan, R.; Veloso, C.M. Characterization of starch-based bioplastics from jackfruit seed plasticized with glycerol. J. Food Sci. Technol. 2018, 55, 278-286, https://doi.org/10.1007/s13197-017-2936-6.

36. Alizadeh-Sani, M.; Ehsani, A.; Moghaddas Kia, E.; Khezerlou, A. Microbial gums: introducing a novel functional component of edible coatings and packaging. Appl. Microbiol. Biotechnol. 2019, 103, 6853-6866, https://doi.org/10.1007/s00253-019-09966-x. 
37. Sofiah; Yuniar; Aznury, M.; Melianti. Mechanical Properties of Bioplastics Product from Musa Paradisica Formatypica Concentrate with Plasticizer Variables. Journal of Physics: Conference Series 2019, 1167, 012048, https://doi.org/10.1088/1742-6596/1167/1/012048.

38. Ali, C.; Hyunjin, M.; Jiajia, Z.; Yang, Q.; Tarnuma, T.; Jun, H. J.; Mahdi, A.-O.; Susannah, L. S.; Sangwon, S. Degradation Rates of Plastics in the Environment. ACS Sustain Chem Eng. 2020, 8 (9), 3494-3511. https://doi.org/10.1021/acssuschemeng.9b06635.

39. Tappiban, P.; Sraphet, S.; Srisawad, N.; Peng, W.; Huaxin, H.; Duncan, R. S.; Jinsong, B.; Kanokporn, T. Effects of cassava variety and growth location on starch fine structure and physicochemical properties. Food Hydrocoll. 2020, 108, 106074, 1-11. https://doi.org/10.1016/j.foodhyd.2020.106074.

40. Battistelli, D; Ferreira, D; Costa, S; Santulli, C; Fangueiro, R. Conductive Thermoplastic Starch (TPS) Composite Filled with Waste Iron Filings. Emerging Science Journal, 2020, 4(3), 136-147. http://dx.doi.org/10.28991/esj-2020-01218.

41. Han Lyn, F.; Chin Peng, T.; Ruzniza, M.Z.; Nur Hanani, Z.A. Effect of oxidation degrees of graphene oxide (GO) on the structure and physical properties of chitosan/GO composite films. Food Packaging and Shelf Life 2019, 21, 100373, https://doi.org/10.1016/j.fps1.2019.100373.

42. Jia Y, Hu C, Shi P, Xu Q, Zhu W, Liu R. Effects of cellulose nanofibrils/graphene oxide hybrid nanofiller in PVA nanocomposites. Int $J$ Biol Macromol. 2020, 15;161, 223-230. doi: 10.1016/j.ijbiomac.2020.06.013.https://doi.org/10.1016/j.ijbiomac.2020.06.013.

43. Basiak, E.; Lenart, A.; Debeaufort, F. How glycerol and water contents affect the structural and functional properties of starch-based edible films. Polymers 2018, 10, 412, https://doi.org/10.3390/polym10040412.

44. Srikhao, N.; Kasemsiri, P.; Ounkaew, A.; Narubeth, L.; Manunya, O.; Uraiwan, P.; Salim, H.; Prinya, C. Bioactive Nanocomposite Film Based on Cassava Starch/Polyvinyl Alcohol Containing Green Synthesized Silver Nanoparticles. J Polym Environ, 2020, Article in press. https://doi.org/10.1007/s10924-020-01909-2

45. Cheong, Y.K.; Arce, M.P.; Benito, A.; Chen, D.; Luengo, C. N.; Kerai, L.V.; Rodríguez, G.; Valverde, J.L.; Vadalia, M.; Cerpa-Naranjo, A.; Ren, G. Synergistic Antifungal Study of PEGylated Graphene Oxides and Copper Nanoparticles against Candida albicans. Nanomaterials (Basel). 2020, 10(5), 819: 1-19. https://doi.org/10.3390/nano10050819.

46. Kannan, B. N.; Park, G.T.; Sung, S. H. Antibacterial properties of starch-reduced graphene oxide-polyiodide nanocomposite. Food Chem. 2020, Article In Press. https://doi.org/10.1016/j.foodchem.2020.128385.

47. Akhtari, M., Dehghani-Firouzabadi, M., Aliabadi, M., \& Arefkhani, M. Effect of graphene oxide nanoparticle coatings on the strength of packaging paper and its barrier and antibacterial properties. Bois Et Forets Des Tropiques 2019, 342, 69-78. https://doi.org/10.19182/bft2019.342.a31796. 